\title{
Art in Science Competition invites artworks to the annual exhibition on ISMB 2018 in Chicago [version 1; peer review:
}

\section{not peer reviewed]}

\author{
Lonnie Welch¹, Bruno Gaeta22, Diane E. Kovats (D)3, Milana Frenkel Morgenstern (iD) \\ ${ }^{1}$ School of EECS, Ohio University, Athens, OH, USA \\ ${ }^{2}$ School of Computer Science and Engineering, University of New South Wales, Sydney, New South Wales, Australia \\ 3International Society for Computational Biology, Bathesda, MD, USA \\ ${ }^{4}$ The Azrieli Faculty of Medicine, Bar-Ilan University, Safed, Israel
}

V1 First published: 19 Mar 2018, 7(ISCB Comm J):337

https://doi.org/10.12688/f1000research.14242.1

Latest published: 19 Mar 2018, 7(ISCB Comm J):337

https://doi.org/10.12688/f1000research.14242.1

\begin{abstract}
The International Society of Computational Biology and Bioinformatics (ISCB) brings together scientists from a wide range of disciplines, including biology, medicine, computer science, mathematics and statistics. Practitioners in these fields are constantly dealing with information in visual form: from microscope images and photographs of gels to scatter plots, network graphs and phylogenetic trees, structural formulae and protein models to flow diagrams, visual aids for problem-solving are omnipresent. The ISCB Art in Science Competition 2017 at the ISCB/ECCB 2017 conference in Prague offered a way to show the beauty of science in art form. Past artworks in this annual exhibition at ISMB combined outstanding beauty and aesthetics with deep insight that perfectly validated the exhibit's approach or went beyond the problem's solution. Others were surprising and inspiring through the transition from science to art, opening eyes and minds to reflect on the work being undertaken.
\end{abstract}

\section{Keywords}

art, science, competition

This article is included in the Bioinformatics gateway.

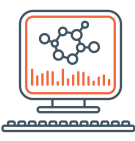

\section{Not Peer Reviewed}

This article is an Editorial and has not been subject to external peer review.

Any comments on the article can be found at the end of the article. 
Corresponding authors: Diane E. Kovats (dkovats@iscb.org), Milana Frenkel Morgenstern (milana.morgenstern@biu.ac.il)

Author roles: Welch L: Conceptualization, Writing - Original Draft Preparation, Writing - Review \& Editing; Gaeta B: Conceptualization, Supervision; Kovats DE: Supervision; Frenkel Morgenstern M: Conceptualization, Writing - Original Draft Preparation, Writing - Review \& Editing

Competing interests: No competing interests were disclosed.

Grant information: The author(s) declared that no grants were involved in supporting this work.

Copyright: $\odot 2018$ Welch L et al. This is an open access article distributed under the terms of the Creative Commons Attribution License, which permits unrestricted use, distribution, and reproduction in any medium, provided the original work is properly cited.

How to cite this article: Welch L, Gaeta B, Kovats DE and Frenkel Morgenstern M. Art in Science Competition invites artworks to the annual exhibition on ISMB 2018 in Chicago [version 1; peer review: not peer reviewed] F1000Research 2018, 7(ISCB Comm J):337 https://doi.org/10.12688/f1000research.14242.1

First published: 19 Mar 2018, 7(ISCB Comm J):337 https://doi.org/10.12688/f1000research.14242.1 
The International Society of Computational Biology and Bioinformatics (ISCB) brings together scientists from a wide range of disciplines, including biology, medicine, computer science, mathematics and statistics. Practitioners in these fields are constantly dealing with information in visual form: from microscope images and photographs of gels to scatter plots, network graphs and phylogenetic trees, structural formulae and protein models to flow diagrams, visual aids for problem-solving are omnipresent. The ISCB Art in Science Competition 2017 at the ISCB/ECCB 2017 conference in Prague offered a way to show the beauty of science in art form. Past artworks in this annual exhibition at ISMB combined outstanding beauty and aesthetics with deep insight that perfectly validated the exhibit's approach or went beyond the problem's solution. Others were surprising and inspiring through the transition from science to art, opening eyes and minds to reflect on the work being undertaken.

Thirty unique pieces were showcased in the Art in Science competition at ISCB/ECCB 2017 in Prague. There winners (reproduced below) were selected by the Art in Science review committee.

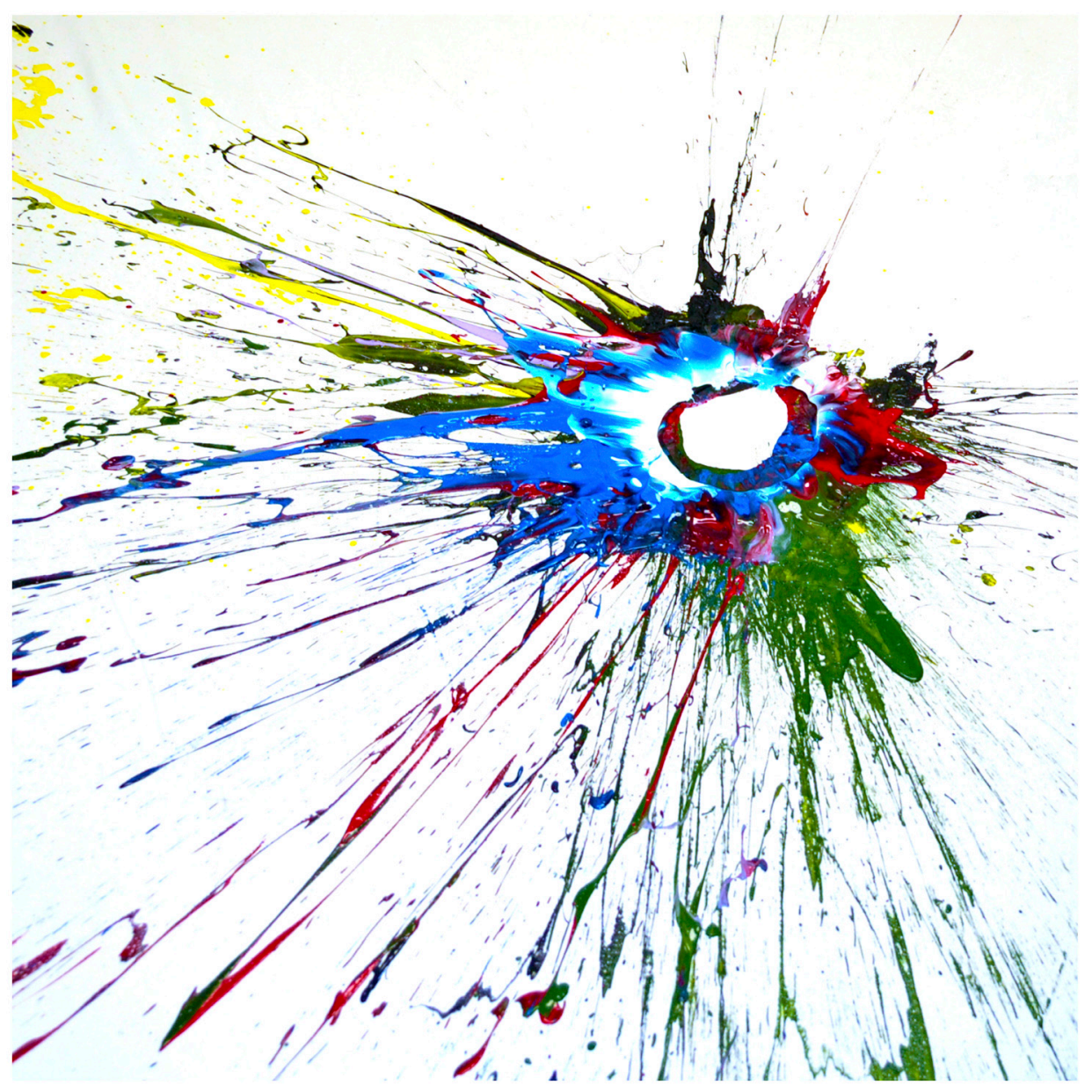

Nick Schurch, University of Dundee

Chris Cole, University of Dundee, United Kingdom

Artwork title: ImpactFactor 


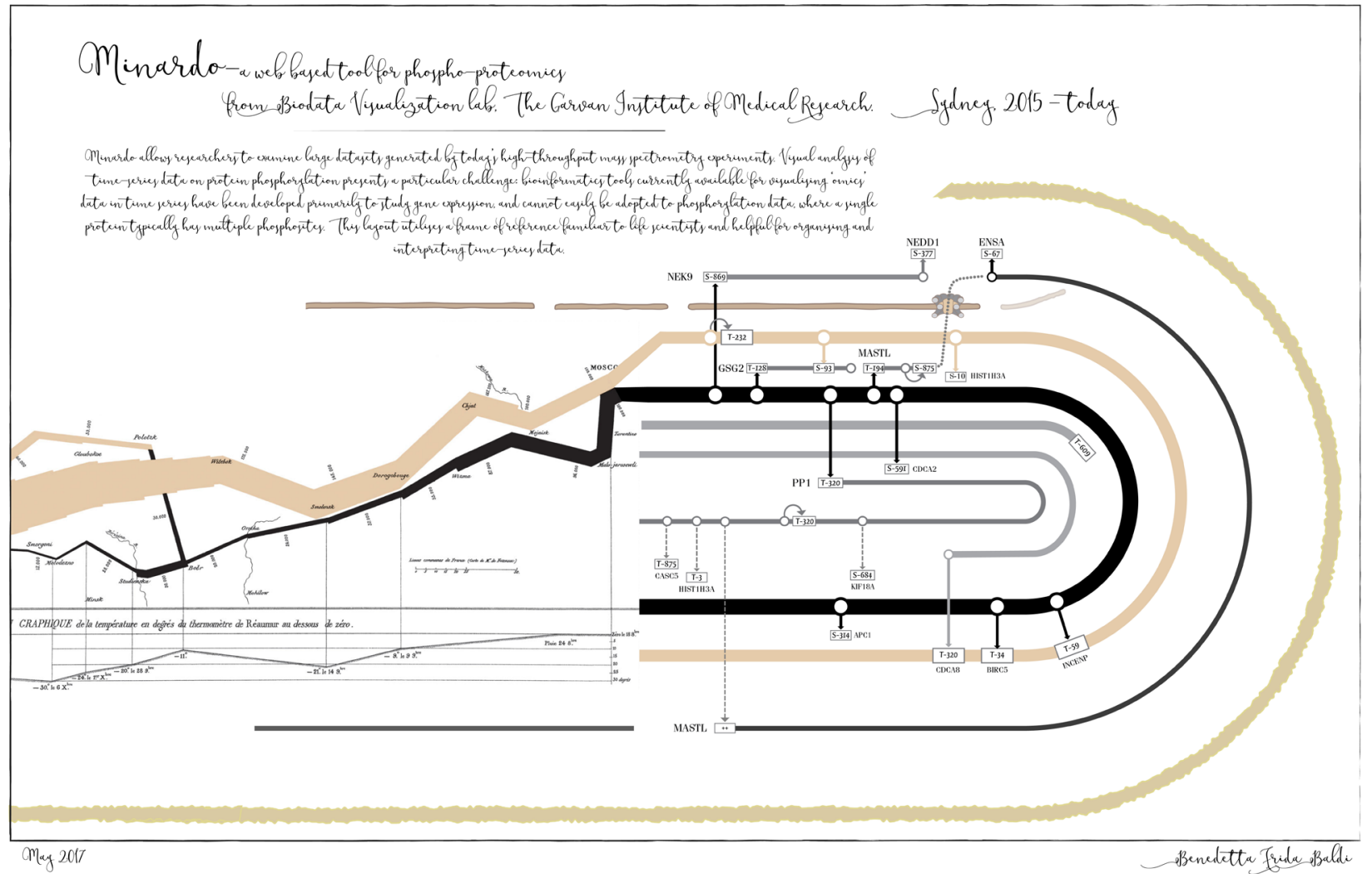

Benedetta Frida Baldi, The Garvan Institute of Medical Research Artwork title: Minard->o: how Napoleon marched into phosphoproteomic data

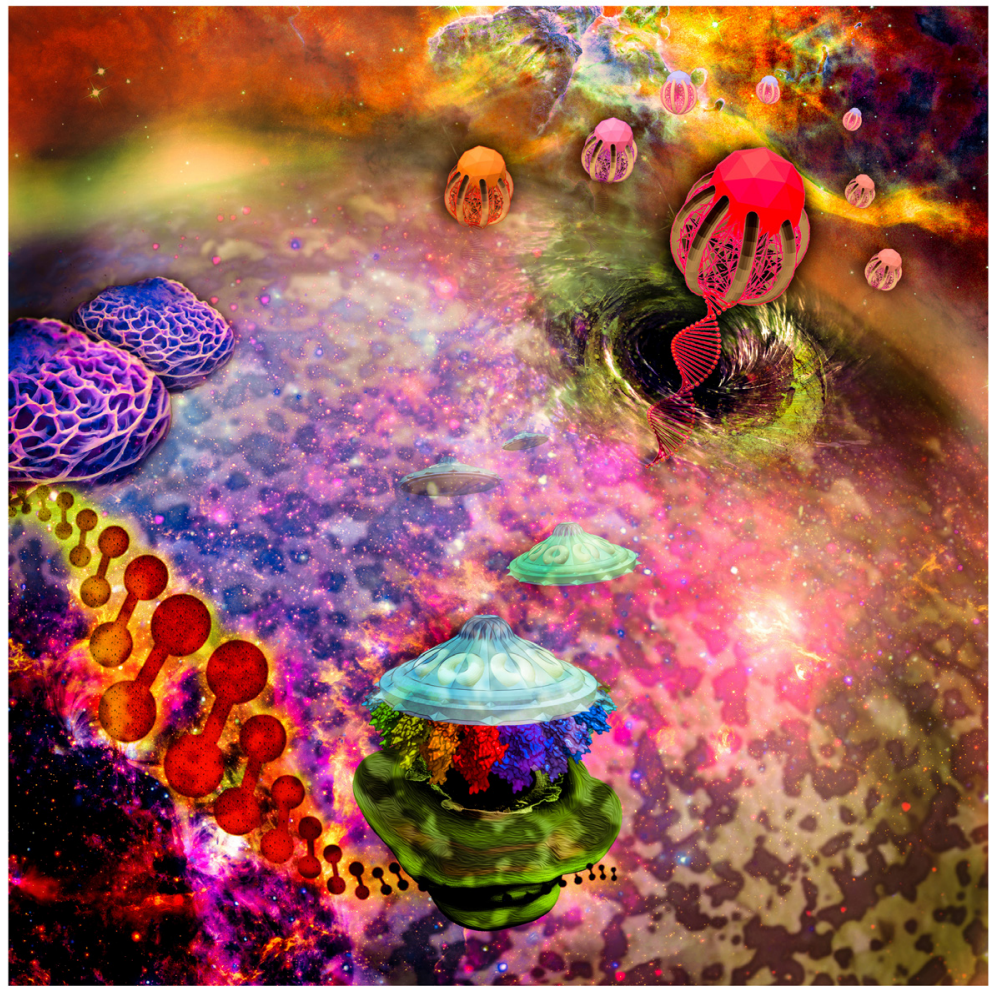

Aviad Sivan, Bar Ilan University

Artwork title: Invasion by viruses 
ISCB invites submissions to the 2018 ISCB Art in Science competition. All interested members may submit images that have been generated as part of a research project and other creative efforts that involve scientific concepts or employ scientific tools and methods. Submissions will be reviewed by a panel of judges. All submissions will be invited to ISMB 2018 in Chicago Illinois, USA, to display their work. The winning submission will be announced during the ISCB Town Hall and presented with a \$200 USD prize, as well as be the feature cover image for the ISCB Fall Newsletter.

Submission page: https://www.iscb.org/submissions/index.php? id $=236$
The Art in Science review committee (2018): Milana Frenkel-Morgenstern, Bar-Ilan University, chair

Lonnie Welch, Ohio University, co-chair

Bruno Gaeta, UNSW Australia, co-chair

Mickey Kosloff, University of Haifa, reviewer

Competing interests

No competing interests were disclosed.

Grant information

The author(s) declared that no grants were involved in supporting this work. 
The benefits of publishing with F1000Research:

- Your article is published within days, with no editorial bias

- You can publish traditional articles, null/negative results, case reports, data notes and more

- The peer review process is transparent and collaborative

- Your article is indexed in PubMed after passing peer review

- Dedicated customer support at every stage

For pre-submission enquiries, contact research@f1000.com 